\title{
The Mediating Effect of Financial Motives in the Association between Entrepreneurial Experience and Subjective Well-Being: Evidence from Japan
}

\author{
Yuji Honjo $^{1}$ (D) Kenta Ikeuchi ${ }^{2} \cdot$ Hiroki Nakamura $^{3}$
}

Received: 18 May 2020 / Accepted: 5 April 2021 /Published online: 11 May 2021

(C) The Author(s) 2021

\begin{abstract}
This study investigates the relationship between entrepreneurial experience and subjective well-being. Using an original survey on subjective well-being, entrepreneurial experience, level of wealth (inferred from observed variables of income, cash, and assets), and personal attributes of 10,001 individuals in Japan, we examine the factors that mediate the association between entrepreneurial experience and subjective wellbeing. We measure entrepreneurial experience as an individual's experience in funding, owning, and running a corporation. We consider the mediating effect of the level of wealth on subjective well-being because entrepreneurial well-being is associate with wealth derived from income, cash, and assets. Our results provide no significant evidence that individuals with entrepreneurial experience have higher subjective wellbeing. However, we find a positive indirect effect of entrepreneurial experience on subjective well-being through wealth and a negative indirect effect through debt. The findings of this study indicate the importance of considering the mediating effect of financial motives in entrepreneurial well-being.
\end{abstract}

Keywords Debt $\cdot$ Entrepreneur $\cdot$ Generalized structural equation modeling $\cdot$ Mediating effect $\cdot$ Subjective well-being $\cdot$ Wealth

Yuji Honjo

yhonjo@tamacc.chuo-u.ac.jp

Kenta Ikeuchi

ikeuchi-kenta@ rieti.go.jp

Hiroki Nakamura

hnakamu@iss.u-tokyo.ac.jp

Extended author information available on the last page of the article 


\section{Introduction}

Subjective well-being represents a broad category of phenomena that includes people's emotional responses, domain satisfactions, and global judgements of life satisfaction (Diener et al. 1999: p.277). This has recently come to the forefront in research on entrepreneurship (e.g., Kibler et al. 2019; Wiklund et al. 2019). The extant literature also highlights the relationship between an individual's experience in starting and running a business - that is, entrepreneurial experience-and subjective well-being (e.g., Carree and Verheul 2012; Sherman et al. 2016). Entrepreneurial well-being indicates the experience of satisfaction, positive affect, infrequent negative affect, and psychological functioning in relation to developing, starting, growing, and running an entrepreneurial venture (Wiklund et al. 2019: p.579). Some scholars have argued that entrepreneurial well-being is more relevant for better understanding the behavior and performance of entrepreneurs (e.g., Shepherd et al. 2019; Marshall et al. 2020).

Numerous scholars have examined the factors that affect subjective well-being (e.g., Dolan et al. 2008; Stephan 2018). Indeed, there are various motives for new firm creation (Feldman and Bolino 2000; Carree and Verheul 2012). Several studies have emphasized nonpecuniary motives, such as procedural utility and autonomy (e.g., Benz and Frey 2008a; Block and Koellinger 2009). Meanwhile, whether financial motives (monetary motives), often measured by wealth and income, have a significant effect on subjective well-being - in other words, money buys happiness - has been debated in the literature (e.g., Kahneman and Deaton 2010; Stevenson and Wolfers 2013). In practice, empirical studies have found a positive effect of wealth and income on subjective well-being (e.g., Headey and Wooden 2004; Benz and Frey 2008a; Block and Koellinger 2009). At the same time, some scholars provided evidence that the average income of entrepreneurs is lower than that of employees (e.g., Hamilton 2000; Binder and Coad 2013; Åstebro et al. 2014). These findings force us to question why individuals become entrepreneurs from financial motives, despite the possibility that subjective well-being decreases due to lower incomes. Moreover, the process of achieving entrepreneurial well-being seems complex (Abreu et al. 2019). To resolve such complex relationships, some scholars have shed light on mediating processes in entrepreneurial well-being (e.g., Shir et al. 2019; Nikolaev et al. 2020a, 2020b). However, it remains debatable as to how entrepreneurs acquire subjective well-being via financial motives, including the mediating process. To the best of our knowledge, there is a paucity of research on the mediating role in entrepreneurial well-being, including the indirect effect of entrepreneurial experience on subjective well-being. Understanding this aspect would assist us in improving our understanding of the nature of entrepreneurship.

This study investigates the relationship between entrepreneurial experience and subjective well-being. Using an original survey on subjective well-being, entrepreneurial experience, level of wealth (inferred from observed variables of income, cash, and assets), and personal attributes of 10,0001 individuals in Japan, we examine the factors that mediate the association between entrepreneurial experience and subjective wellbeing. We measure entrepreneurial experience as an individual's experience in funding, owning, and running a corporation. We consider the mediating effect of the level of wealth on subjective well-being because entrepreneurial well-being is associated with wealth derived from income, cash, and assets. By doing so, we identify how subjective 
well-being is shaped by entrepreneurial experience. This can help improve our understanding of entrepreneurship in national and regional economies.

Our results provide no significant evidence that individuals with entrepreneurial experience have higher subjective well-being. Rather, entrepreneurial experience has a negative direct effect on subjective well-being when we control for the level of wealth, measured by household income, and individual cash and assets, in addition to personal attributes. We also find a positive indirect effect of entrepreneurial experience on subjective well-being through wealth and a negative indirect effect through debt. The results indicate that individuals with higher household income and individual cash and assets are more likely to have higher subjective well-being. In contrast, individuals with debt burdens are less likely to have higher subjective well-being. The findings suggest that the level of wealth plays a critical role in determining entrepreneurial well-being. Moreover, a debt burden becomes an obstacle to increasing entrepreneurial well-being.

This study contributes to the relevant literature by providing novel findings from an original survey. Although prior research on entrepreneurship has provided evidence on the presence of entrepreneurial well-being, there is still limited knowledge on the mediating effect of financial motives on entrepreneurial well-being. Our results indicate that entrepreneurial well-being does not simply result from starting a business. Even if individuals become entrepreneurs to seek their own interests, they do not necessarily have higher subjective well-being by starting their businesses. Rather, the level of wealth, which consists of financial motives, may enable individuals to secure subjective well-being derived from entrepreneurial experience. Our findings illustrate how entrepreneurs experience and exhibit subjective well-being.

The remainder of this study is organized as follows. The subsequent section explains the research background. Next, we discuss the data and methods used. After that, the estimation results are presented. Finally, we discuss implications and present conclusions of this study.

\section{Research Background and Theoretical Arguments}

\section{Entrepreneurship and Subjective Well-Being}

In recent years, scholars have paid increasing attention to entrepreneurship and subjective well-being (e.g., Uy et al. 2017; Ryff 2019; Shir et al. 2019; Nikolaev et al. 2020a). The subjective approach to well-being, which includes not only pleasure attainment and pain avoidance (hedonic and desire based) but also emphasize vitality, meaning, and self-realization (eudaimonic) of mental wellness, has been prevalent in the literature (e.g., Wills 2009; Wiklund et al. 2019). Most studies examining the relationship between entrepreneurship and well-being have adopted general subjective measures of well-being, such as life satisfaction and positive affect, or focusing on contextspecific constructs of business- and work-related satisfaction (e.g., Wiklund et al. 2019). Subjective well-being, such as life satisfaction, happiness, worry, and depression, provides a more holistic view. In contrast, objective measures of well-being, such as income and expenditure, are only partially related to how people experience and evaluate their lives (Bhuiyan and Artjoms 2019). 
Essentially, it is thought that individuals' decisions to become entrepreneurs are related to their personal net worth and self-interests (Van de Ven et al. 2007; Lofstrom et al. 2014). In this context, many studies have addressed entrepreneurs' job and life satisfaction (e.g., Binder and Coad 2013; Millán et al. 2013; Lindblom et al. 2020). Empirical evidence indicates that people who are actively starting and running new businesses report significantly higher levels of job and life satisfaction, despite earning lower incomes and working longer hours (Benz and Frey 2008a, 2008b). Meanwhile, some studies emphasize that starting new businesses leads to job stress (Monsen and Boss 2009) and feelings of grief (Jenkins et al. 2014).

To date, numerous scholars have explored the differences in job and life satisfaction between self-employed (i.e., entrepreneurs) and employed individuals (i.e., employees) (e.g., Andersson 2008; Van der Zwan et al. 2018; Kibler et al. 2019). It is plausible that entrepreneurs experience an increase in subjective well-being while enjoying their new businesses. Individuals have less incentive to become entrepreneurs unless they expect higher subjective well-being. Indeed, research on individuals' decisions to become entrepreneurs has established that self-employed individuals have higher job satisfaction than employees (e.g., Blanchflower and Oswald 1998; Blanchflower 2000; Andersson 2008; Benz and Frey 2008b). The findings of these studies indicate a positive relationship between entrepreneurship and subjective well-being. In particular, psychological motives, such as autonomy, competence, and relatedness, are associated with an increase in subjective well-being (Cooper and Peake 2018). ${ }^{1}$

Conversely, Naudé et al. (2014) found a negative relationship across nations using the Global Entrepreneurship Monitor (GEM) data. This relationship partly indicates that necessity entrepreneurship - individuals who are pushed into entrepreneurship because all other options for work are either absent or unsatisfactory - is related to entrepreneurial well-being due to a lack of better alternatives (Block and Koellinger 2009; Kautonen and Palmroos 2010). In other words, some individuals are selfemployed because they cannot find any suitable jobs in existing firms. Meanwhile, Tiefenbach and Kohlbacher (2015) found a negative relationship between entrepreneurship and subjective well-being using data on Japanese individuals. It is likely that individuals with entrepreneurial experience have lower subjective well-being, even though the unemployment rate has been low in Japan (Akram 2019). This may suggest that entrepreneurial well-being is possibly determined regardless of a lack of other alternatives.

Essentially, it is conceivable that subjective well-being is associated with business outcomes. Several scholars have addressed the relationship between business outcomes and subjective well-being (e.g., Lyubomirsky et al. 2005; Dijkhuizen et al. 2018). For entrepreneurs, subjective well-being is indeed tied to business outcomes (Sherman et al. 2016). In addition, some studies have examined the relationship between goal attainment and subjective well-being in the literature on psychology (e.g., Sheldon and Houser-Marko 2001; Sheldon et al. 2002). It is thought that individuals who successfully pursue their goals experience a higher level of subjective well-being (Klug and Maier 2015). Moreover, entrepreneurial success is found to be positively associated

\footnotetext{
${ }^{1}$ Satisfying psychological motives, such as autonomy (experiencing choice), competence (experiencing effectiveness), and relatedness (experiencing connectedness with others), is considered to influence individual motivation (Deci and Ryan 2000).
} 
with life satisfaction (Przepiorka 2017). In this regard, business outcomes, which facilitate goal attainment, are nontrivial in predicting entrepreneurial well-being.

Moreover, nascent entrepreneurs who a priori have less information on business environment cannot perfectly predict business outcomes prior to starting businesses. It is plausible that nascent entrepreneurs recognize real conditions after starting their businesses (Baron and Henry 2010). This notion is derived from the learning process of achieving entrepreneurial well-being, based on the concept of a learning model proposed by Jovanovic (1982). It is conceivable that nascent entrepreneurs are encouraged or discouraged by unexpected outcomes, which will increase or decrease entrepreneurial well-being. A positive gap between expected and real outcomes, which increases wealth more than expected, could explain the positive relationship between entrepreneurship and subjective well-being. In contrast, a negative gap between expected and real outcomes, which decreases wealth less than expected, could explain the negative relationship between entrepreneurship and subjective well-being. More importantly, individuals who become entrepreneurs are more susceptible to certain cognitive biases, and are more likely to be overconfident than others (Forbes 2005; Koellinger et al. 2007). Such entrepreneurs may rather encounter unexpected hardship, including excess working hours, after starting their businesses.

\section{Determinants of Entrepreneurial Well-Being and Financial Motives}

There are various motives for new firm creation. Individuals pursue entrepreneurship for personal and idiosyncratic reasons (Feldman and Bolino 2000; Carree and Verheul 2012; Wiklund et al. 2019). Numerous scholars have examined the factors affecting entrepreneurial well-being, in other words, what makes entrepreneurs happy (e.g., Carree and Verheul 2012). As is often argued, entrepreneurial well-being depends on personality traits, such as self-efficacy (Boyd and Vozikis 1994; Bradley and Roberts 2004). In this context, psychological motives have been highlighted in research on entrepreneurship (e.g., Shir et al. 2019; Wiklund et al. 2019). Some studies have emphasized the importance of entrepreneurs' mental and physical health (e.g., Hessels et al. 2018; Stephan 2018; Hatak and Zhou 2021). Entrepreneurial well-being is also derived from independence and creativity (Block and Koellinger 2009). In addition, autonomy and flexibility have a significant impact on entrepreneurial well-being (Parasuraman and Simmers 2001; Tremblay and Genin 2008). More interestingly, entrepreneurs may enjoy procedural utility, which indicates that people value not only outcomes but also the conditions and processes leading to the outcomes (Benz and Frey 2008a). These suggest that nonpecuniary motives influence entrepreneurial well-being. At the same time, there is room for further evidence on how individuals acquire subjective well-being owing to the motives for becoming entrepreneurs. ${ }^{2}$

Financial rewards and consequences are not trivial for entrepreneurship (Carter 2011). Several scholars have addressed the importance of financial satisfaction or subjective well-being (e.g., Van Praag et al. 2003; Brüggen et al. 2017). Indeed, many studies have found a positive effect of wealth and income on subjective well-being (e.g., Headey and Wooden 2004; Benz and Frey 2008a; Block and Koellinger 2009).

\footnotetext{
${ }^{2}$ Cueto and Pruneda (2017) argued that entrepreneurs have higher levels of life satisfaction when they have a preference for self-employment.
} 
While nonpecuniary motives influence entrepreneurial well-being, financial motives must be a major incentive for individuals to engage in entrepreneurial activity (Block and Koellinger 2009). Entrepreneurs prefer to manage their firms for sufficient financial means to live a comfortable life (Carree and Verheul 2012). It is conceivable that entrepreneurs who are satisfied with their standard of living through sufficient income are more likely to have higher subjective well-being. Moreover, many, but not all, individuals expect successful outcomes when starting new businesses. Some of them may seek financial well-being, such as large capital gains and profits through successful outcomes. In particular, individuals who expect profits are more encouraged or discouraged by their income and wealth levels. As entrepreneurs' task is to seek the successful outcomes of start-up firms founded by themselves, entrepreneurial wellbeing is associated with firm performance. In this respect, entrepreneurial success is considered to be significantly associated with better business outcomes (Dijkhuizen et al. 2018). Given that the level of income partly reflects business outcomes, it is also conceivable that entrepreneurial well-being is associated with the level of income.

Since the seminal work of Easterlin (1974) regarding the association between economic growth and happiness, the relationship between income and subjective well-being has often been highlighted in the literature (e.g., Stevenson and Wolfers 2008; Binder 2013). Previous studies have demonstrated that subjective well-being depends on the level of wealth (e.g., Cummins 2000; Judge et al. 2010). The sense of financial well-being depends on the objective measures of financial situations, such as the level of income (Porter and Garman 1992). Some scholars provided evidence on a positive relationship between income and subjective well-being (e.g., Block and Koellinger 2009; Millán et al. 2013). These results indicate that entrepreneurial wellbeing is associated with the level of wealth, which can be called financial well-being (Sorgente and Lanz 2017). ${ }^{3}$

In contrast, the level of debt becomes a burden to entrepreneurs and results in a negative effect on entrepreneurial well-being. For instance, Bhuiyan and Artjoms (2019) examined the case of microcredit that has long been hailed as a powerful tool to promote livelihoods and reduce poverty through entrepreneurship in Bangladesh. They found that microcredit borrowing has an indirect negative effect on overall life satisfaction through increased worry. Such financial motives, which are measured by wealth and debt levels in this study, would also play a critical role in determining entrepreneurial well-being.

\section{The Japanese Context}

According to the GEM data, Japan exhibits a lower level entrepreneurship (Honjo 2015; Honjo and Nakamura 2020). The entry rate has been low during a few decades following the collapse of the bubble economy. Moreover, Japan has a lower level of

\footnotetext{
${ }^{3}$ Traditionally, previous studies have examined the impact of financial constraints, often measured by inheritances, on business start-ups (e.g., Evans and Jovanovic 1989; Holtz-Eakin et al. 1994a, 1994b). According to the perspective of financial constraints, it is thought that wealthier individuals are more likely to start businesses (Lofstrom et al. 2014). Meanwhile, Hurst and Lusardi (2004) argued that wealth does not matter in starting a business. They also argued that there is a strong and positive relationship between household wealth and business entry only for households at the very top of the wealth distribution. The causal relationship between entrepreneurship and wealth needs to be further clarified in future investigations.
} 
entrepreneurial attitudes, as measured by subjective perceptions, including confidence in one's skills and ability and risk propensity. These findings suggest that the cautious and prudent attitudes of individuals impede entrepreneurial activity in Japan (Honjo 2015). Conversely, it is desirable how policymakers foster entrepreneurship for future economic growth because of a lower level of entrepreneurship. In this respect, much attention should be paid on how entrepreneurs experience subjective well-being in Japan.

According to the 2017 White Paper on Small and Medium Enterprises in Japan, satisfaction with income in the establishment stage after start-up is lower than before start-up, while satisfaction with work (e.g., freedom and discretion, sense of achievement and enthusiasm, and work content) in the establishment stage after start-up is much higher than before start-up (Small and Medium Enterprise Agency 2017: p.184). This suggests that many individuals a priori have insufficient information and the learning process of achieving entrepreneurial well-being is prominent for entrepreneurs in Japan. It is also possible that the gap between expected and real income discourages entrepreneurial well-being. Meanwhile, "hobby entrepreneurs," who start businesses only for their own interests and skills, have recently been highlighted. However, such entrepreneurs do not necessarily have higher subject well-being compared to others (Small and Medium Enterprise Agency 2019). This suggests that it is difficult to maintain entrepreneurial well-being in Japan, only if entrepreneurs pursue their own interests and skills. Subjective well-being may be more susceptible to social evaluation, including economic performance.

As discussed, prior literature has established that self-employed individuals have higher job satisfaction than employees (e.g., Blanchflower and Oswald 1998; Blanchflower 2000; Andersson 2008; Benz and Frey 2008b). However, as already mentioned, Tiefenbach and Kohlbacher (2015) found a negative relationship between entrepreneurship and subjective well-being, using data from the 2011 National Survey on Lifestyle Preference in Japan. Their findings provide inconsistent evidence regarding the positive relationship between entrepreneurship and subjective well-being in Japan (Benz and Frey 2008b). However, other studies did not find significant results for the relationship between entrepreneurship and subjective well-being (e.g., Oshio and Kobayashi 2011).

In Japan, individuals prefer stable working status, based on income and employment security, to the risky and unstable path of entrepreneurs. This suggests that career paths and family plans are more rigid and homogenous than in Western societies (Tiefenbach and Kohlbacher 2015). ${ }^{4}$ Japan has a lower level of interest in self-employment, although the ratio of self-employed individuals in Japan is not lower, compared to some developed countries (Blanchflower et al. 2001). In addition, individuals in Japan seem to have more opportunities because the unemployment rate has been low in recent years (Akram 2019). These suggest that some individuals tend to be obliged to choose self-employment in accordance with the succession of businesses and technologies developed by their family members.

Whereas entrepreneurship is directly linked to subjective well-being, it is possible that the indirect effect of entrepreneurial experience on subjective well-being, including

\footnotetext{
${ }^{4}$ Taniguchi and Potter (2016) emphasized that social relationships, including neighbor relationships, enhance subjective well-being, especially in the Eastern Societies, such as Japan.
} 
mediating factors, is more significant. This may determine subjective well-being. However, to the best of our knowledge, there is a paucity of research on the mediating effect of other factors, which would assist us in having a better understanding of the nature of entrepreneurship in countries with less entrepreneurial well-being, such as Japan.

\section{Hypotheses Development}

\section{Direct Effect of Entrepreneurial Experience on Subjective Well-Being}

As discussed, entrepreneurial well-being depends on various motives. Many entrepreneurs, including the self-employed, may simply consider the achievement of their own personal interests. Essentially, individuals have less incentive to become entrepreneurs unless they expect higher subjective well-being. Indeed, the findings of previous studies indicate a positive relationship between entrepreneurship and subjective wellbeing (e.g., Blanchflower and Oswald 1998; Blanchflower 2000; Andersson 2008; Benz and Frey 2008b). In this context, a positive relationship between entrepreneurship and subjective well-being is hypothesized.

However, it is not easy for individuals to perfectly predict business outcomes prior to starting businesses. According to the learning process of achieving entrepreneurial well-being, individuals may rather recognize real conditions after starting their businesses. If individuals encounter unexpected hardship, a negative relationship between entrepreneurship and subjective well-being emerges. While some studies provided support for a positive relationship between entrepreneurship and subjective wellbeing (e.g., Blanchflower and Oswald 1998; Blanchflower 2000; Andersson 2008), mixed results were founded for Japanese self-employed individuals (e.g., Blanchflower et al. 2001; Benz and Frey 2008b; Oshio and Kobayashi 2011; Tiefenbach and Kohlbacher 2015). In addition, others found that self-employed individuals work longer hours than those employed by organizations (e.g., Hyytinen and Ruuskanen 2007). Such working conditions may negatively affect entrepreneurial well-being. In these respects, it is unclear whether entrepreneurs have higher life satisfaction than employees. Thus, we test the following hypotheses:

- H1a: Entrepreneurial experience is positively associate with subjective well-being.

- H1b: Entrepreneurial experience is negatively associated with subjective wellbeing.

\section{Indirect Effect of Entrepreneurial Experience through Wealth}

In addition to the relationship between entrepreneurship and subjective well-being, the relationship between entrepreneurship, including self-employed individuals, and income has been debated in the literature (e.g., Hurst and Lusardi 2004; Carter 2011). Some scholars provided evidence that the average income of entrepreneurs is lower than that of employees (e.g., Hamilton 2000; Binder and Coad 2013; Åstebro et al. 2014). These findings do not support the notion that individuals with entrepreneurial 
experience have higher income than employees, although these individuals do face more volatile income. Meanwhile, the relationship between individuals' income level and subjective well-being has been debated in the existing literature (e.g., Cummins 2000; Clark et al. 2008). Presumably, several individuals care about aspects other than money when they start businesses. Moreover, nonpecuniary motives play a more critical role in driving entrepreneurial well-being, However, as discussed, financial motives are a major incentive for individuals to engage in entrepreneurial activity (Block and Koellinger 2009). While some individuals possibly seek their own interests, it is unlikely that individuals pay less attention to business outcomes. Furthermore, individuals who are obliged to choose self-employment at that time may have higher subjective well-being by reaching a certain level of wealth. In practice, previous studies have found a positive effect of wealth and income on subjective well-being (e.g., Headey and Wooden 2004; Benz and Frey 2008a; Block and Koellinger 2009).

As already mentioned, the process of achieving entrepreneurial well-being is complex (Abreu et al. 2019). While some individuals have higher subjective well-being through entrepreneurial experience, others may evaluate subjective well-being based on financial motives. Presumably, entrepreneurial experience has direct and indirect effects on subjective well-being. The mediating role in entrepreneurial well-being is critical for business start-ups. In recent years, some scholars have identified this mediating role using a multi-path mediation model with structural equation modelling (SEM) approach (e.g., Nikolaev et al. 2020a; Shir et al. 2019). In particular, Nikolaev et al. (2020b) examined the mediating effect of psychological functioning on subjective well-being. Their results emphasized the importance of the direct and indirect effects of self-employment. While they considered psychological functioning in their analysis, they did not pay attention to the mediating effect of financial motives. It is possible that the mediating effect of financial motives is nontrivial in determining subjective wellbeing. Furthermore, to the best of our knowledge, the mediating effect of financial motives, such as the level of wealth, on entrepreneurial well-being has been ignored in the existing literature. Distinguishing between the direct and indirect effects, we identify the channels through which entrepreneurial experience is related to subjective well-being. By doing so, we can articulate how entrepreneurial experience is associated with subjective well-being. We test the following hypotheses:

H2a: Entrepreneurial experience is positively associated with the level of wealth. H2b: Entrepreneurial experience is negatively associated with the level of wealth. H3: The level of wealth is positively associated with subjective well-being.

\section{Indirect Effect of Entrepreneurial Experience through Debt}

Furthermore, some entrepreneurs increase debt because of investment in new businesses. Financial motives related to debt may affect entrepreneurial well-being. Specifically, the debt burden reduces entrepreneurial well-being. We also examine the indirect effects of the level of debt, in addition to the level of wealth, on subjective wellbeing. Thus, we test the following hypotheses:

H4: Entrepreneurial experience is positively associated with the level of debt. 
H5: The level of debt is negatively associated with subjective well-being.

The mediating effect of financial motives, including the level of debt, is considered significant. It is also plausible that the relationship between entrepreneurship and subjective well-being depends on financial motives. Such investigations on the mediating role in entrepreneurial well-being assist us in gaining a better understanding of how to promote entrepreneurship in the economy.

\section{Data and Methods}

\section{Data Collection}

The data used in this study come from a smartphone and online computer survey, "Internet Survey on the Characteristics and Decision-Making of Potential Entrepreneurs and Angel Investors" from our research project at the Research Institute of Economy, Trade, and Industry (RIETI), Japan. In the survey, we asked individuals their experiences in and attitudes toward business start-ups and investments to identify the proportions of entrepreneurs and angel investors in Japan. We targeted individuals aged 18 to 79, who were assigned according to gender, age, and prefectures in the survey. Rakuten Research, Inc. (currently, Rakuten Insight, Inc.), subcontracted by the RIETI, conducted this survey in May $2018 .{ }^{5}$

In this study, respondents were randomly selected by Rakuten Research. To construct a sample without a bias, Rakuten Research distributed and collected the questionnaires, in proportion to each prefecture's population by gender and age distribution in Japan. 150,144 individuals were contacted and 13,449 respondents were obtained (response rate: $8.96 \%$ ). We excluded some respondents due to lack of answers for some questions, leaving us with a final sample size of 10,001 individuals.

\section{Methods}

As discussed, the indirect effect of entrepreneurial experience on subjective well-being is nontrivial, while entrepreneurial experience may be directly related to subjective well-being. Thus, we pay more attention to the indirect effect of entrepreneurial experience, in addition to the direct effect, on subjective well-being to identify entrepreneurial well-being. Following the mediation analysis stated by Baron and Kenny (1986), we examine the relationship between entrepreneurial experience and subjective well-being.

Let $Y_{i}^{*}$ denote the level of individual $i$ 's subjective well-being, which is captured by a latent variable. We measure $Y_{i}$ instead of $Y_{i}^{*}$ using a five-point ordinal scale. It is assumed that individual $i$ 's entrepreneurial experience, denoted by $X_{i}$, is related to their subjective well-being, $Y_{i}^{*}$. In addition, the mediating effect of entrepreneurial

\footnotetext{
${ }^{5}$ Rakuten Insight has approximately 2.3 million qualified market research respondents (as of March 2016) in Japan, which are recruited through the users of Rakuten Group services.

For more details, see the website of Rakuten Insight.

https://insight.rakuten.co.jp/en/ [Accessed on January 11, 2020]
} 
experience on subjective well-being exists in individuals, and the mediation term is denoted by $Z_{i}^{*}$, which is captured by a latent variable in this study. Based on Baron and Kenny's (1986) framework, we estimate the following equations:

$$
\begin{gathered}
Y_{i}^{*}=\alpha_{0}+\alpha_{1} X_{i}+e_{1 i}, \\
Z_{i}^{*}=\beta_{0}+\beta_{1} X_{i}+e_{2 i}, \\
Y_{i}^{*}=\gamma_{0}+\gamma_{1} X_{i}+\gamma_{2} Z_{i}^{*}+e_{3 i},
\end{gathered}
$$

where $\alpha_{0}, \alpha_{1}, \beta_{0}, \beta_{1}, \gamma_{0}, \gamma_{1}$, and $\gamma_{2}$ are parameters to be estimated, and $e_{1 i}, e_{2 i}$, and $e_{3 i}$ are error terms. In this case, we obtain the following relationship:

$$
\alpha_{1}=\gamma_{1}+\beta_{1} \gamma_{2}
$$

As shown in Eq. (4), $\alpha_{1}$ can be divided into two effects: the direct effect, $\gamma_{1}$, and indirect effect, $\beta_{1} \gamma_{2}$. To identify the gap between the direct and indirect effects, we calculate the test statistics for $\beta_{1} \gamma_{2} / \sigma_{\beta \gamma}$ where $\sigma_{\beta \gamma}$ is the squared root of the covariance of $\beta_{1}$ and $\gamma_{2}$.

To identify the mediating effect of entrepreneurial experience on subjective wellbeing, we use the SEM approach. There are some advantages of using SEM in the context of mediation analysis (Gunzler et al. 2013; MacKinnon 2017; Hayes 2018). The SEM approach allows us to incorporate latent variables. This approach simplifies the testing of the mediation hypotheses because it is designed, in part, to test more complicated mediation models in a single analysis. The SEM approach can also be used when it includes multiple independent variables, mediation terms (mediators), and dependent variables (outcomes). Indeed, we develop a multi-path mediation model in which wealth and debt mediate the relationship between entrepreneurial experience and subject well-being, partially through a positive effect of wealth.

More importantly, as the mediation term is captured by the latent variable $\left(Z_{i}^{*}\right)$, we identify whether an indirect effect of entrepreneurial experience on subjective wellbeing exists in individuals using mediation analysis with generalized structural equation modelling (GSEM). Our model includes dependent variables (response variables) measured by an ordinal scale, such as subjective well-being and annual income. GSEM is applicable when we use SEM with continuous and discrete (e.g., binary and ordinal) variables. Therefore, we employ GSEM in this study to capture the mediation term.

\section{Variables}

Using data on subjective well-being and personal attributes in the sample of individuals, we identify the relationship between entrepreneurial experience and life satisfaction. However, many individuals in the sample have no occupation, and their subjective well-being may be independent of work experience. It is more appropriate to compare individuals with entrepreneurial experience to those with other work experience. When 
examining the impact of entrepreneurial experience, we thus use the subsample of individuals with occupations. As a result, the number of observations in the subsample is 6092 .

The major dependent variable of subjective well-being is measured by life satisfaction $(S A T I S F)$. We use single-item measurement of life satisfaction, following the previous literature (e.g., Decancq et al. 2015; Kibler et al. 2019). To capture subjective well-being, we asked respondents about life satisfaction, and rated their responses using a five-point scale: (1) "not satisfied," (2) "not very unsatisfied," (3) "cannot say either," (4) "somewhat satisfied," and (5) "satisfied."

We define the major independent variable in the estimation model using a binary variable for entrepreneurial experience (ENTRE). In this study, entrepreneurial experience is defined as "experience in funding, owing, and running a company that paid salaries and wages to employees and owners, as well as other expenses, for three or more months." Using this variable, we estimate the relationship between entrepreneurial experience and subjective well-being. We asked individuals about their experiences in business start-ups and angel investments. If an individual has entrepreneurial experience, the variable of entrepreneurial experience (ENTRE) equals 1.

To consider the indirect effect of entrepreneurial experience on subjective wellbeing, we pay attention to wealth, mainly because subjective well-being depends on the level of individual wealth (Cummins 2000; Clark et al. 2008). The level of wealth is often measured by household income and assets (Hurst and Lusardi 2004; Sorgente and Lanz 2017). In this study, we capture wealth ( $Z$ ) using three variables: (i) household income (HINC), (ii) individual cash and deposits $(C A S H)$, and (iii) individual assets other than cash and deposits (ASSET). In addition, as aforementioned, it is hypothesized that the level of debt is negative associated with subjective well-being. In this study, we also use the variable of debt $(D E B T)$, in addition to these variables for wealth.

Moreover, to construct some controls, we include questions on personal attributes, such as educational background and occupation, in addition to the level of household income, individual cash and assets, and debt. We control for personal attributes because subjective well-being depends on individual-specific characteristics. In this study, we capitalize on personal attributes using the following variables: age $(\ln A G E)$, gender (FEMALE), marriage status (MARRIED), and the number of children (NCHILD).

Table 1 indicates the definitions of variables used in this study. Table 2 presents the descriptive statistics of the variables in the subsample of individuals with occupation. The mean of subjective well-being $(S A T I S F)$ is slightly over 3 , and its median is 3 . The mean of entrepreneurial experience (ENTRE) is 0.10 , indicating that approximately $10 \%$ of individuals in the sample have entrepreneurial experience. Figure 1 describes differences in subjective well-being by entrepreneurial experience. While the proportion of (1) "not satisfied" for individuals with entrepreneurial experience $(E N T R E=1)$ is slightly higher than that for individuals without such experience $(E N T R E=0)$, the proportion of (5) "satisfied" for individuals with entrepreneurial experience $(E N T R E=1)$ is higher than that for individuals without such experience $(E N T R E=0)$. Figure 2 depicts the level of wealth by entrepreneurial experience: (a) household income, (b) cash and deposits, and (c) assets other than cash and deposits. Figure 3 depicts the level of debt by entrepreneurial experience. These figures indicate that individuals with entrepreneurial experience are more likely to have higher levels of wealth and debt. 


\section{Estimation Results}

Using the subsample of individuals with occupation, we apply GSEM to describe the relationship between entrepreneurial experience and subjective well-being. Table 3 presents the estimation results for subjective well-being using GSEM. Figure 4 depicts the path diagram of the results presented in Table 3.

As Table 3 shows, we do not find evidence on the positive effect of entrepreneurial experience on subjective well-being. This result may rather indicate a direct negative relationship between entrepreneurial experience and subjective well-being. While our findings are not consistent with those of Benz and Frey (2008b), they are consistent with the findings of Tiefenbach and Kohlbacher (2015) regarding Japanese individuals. Our findings suggest that on average, individuals with entrepreneurial experience do not have higher subjective well-being, even though it is possible that only a few entrepreneurs have much higher subjective well-being than others. In addition, the results indicate that entrepreneurial well-being is associated with the level of wealth.

Table 1 Definitions of variables

\begin{tabular}{|c|c|c|}
\hline Variable & Symbol & Definition \\
\hline $\begin{array}{l}\text { Subjective } \\
\text { well-being }\end{array}$ & SATISF & $\begin{array}{l}\text { Five-point scale: (1) not satisfied, (2) not very unsatisfied, (3) } \\
\text { cannot say either, (4) somewhat satisfied, and (5) satisfied. }\end{array}$ \\
\hline \multirow[t]{3}{*}{$\begin{array}{l}\text { Entrepreneurial } \\
\text { experience }\end{array}$} & ENTRE & $\begin{array}{l}\text { (1) if individuals have entrepreneurial experience, and (0) } \\
\text { otherwise.* }\end{array}$ \\
\hline & $\left(E N T R E \_S T O P\right)$ & $\begin{array}{l}\text { (1) if individuals with entrepreneurial experience retired from } \\
\text { or closed their businesses, and (0) otherwise. }\end{array}$ \\
\hline & $\left(E N T R E \_C O N T I N U E\right)$ & $\begin{array}{l}\text { (1) if individuals with entrepreneurial experience are currently } \\
\text { involved in their business start-up, and (0) otherwise. }\end{array}$ \\
\hline Household income & $H I N C$ & $\begin{array}{l}\text { Seven-point scale: (1)<1 million yen, (2) } 1-3 \text { million yen, (3) } \\
3-5 \text { million yen, (4) 5-10 million yen, (5) 10-20 million } \\
\text { yen, (6) 20-50 million yen, and (7) } 50 \text { million yen+. }\end{array}$ \\
\hline Cash and deposits & $\mathrm{CASH}$ & $\begin{array}{l}\text { Seven-point scale: (1)<1 million yen, (2) } 1-3 \text { million yen, (3) } \\
3-5 \text { million yen, (4) 5-10 million yen, (5) } 10-20 \text { million } \\
\text { yen, (6) 20-50 million yen, and (7) } 50 \text { million yen }+ \text {. }\end{array}$ \\
\hline $\begin{array}{l}\text { Assets other than } \\
\text { cash and deposits }\end{array}$ & ASSET & $\begin{array}{l}\text { Seven-point scale: (1)<1 million yen, (2) } 1-3 \text { million yen, (3) } \\
3-5 \text { million yen, (4) 5-10 million yen, (5) 10-20 million } \\
\text { yen, (6) } 20-50 \text { million yen, and (7) } 50 \text { million yen+. }\end{array}$ \\
\hline Debt & $D E B T$ & $\begin{array}{l}\text { Seven-point scale: (1)<1 million yen, (2) } 1-3 \text { million yen, (3) } \\
3-5 \text { million yen, (4) 5-10 million yen, (5) } 10-20 \text { million } \\
\text { yen, (6) } 20-50 \text { million yen, and (7) } 50 \text { million yen+. }\end{array}$ \\
\hline Gender & FEMALE & (1) if the individual is female, and (0) if the individual is male. \\
\hline Age & $\ln A G E$ & Logarithm of $A G E$ ( $A G E$ is the individual's age). \\
\hline Married & MARRIED & (1) if the individual is married, and (0) otherwise. \\
\hline Number of children & NCHILD & $\begin{array}{l}\text { Five-point scale: (0) no children, (1) one child, (2) two } \\
\text { children, (3) three children, and (4) four or more children. }\end{array}$ \\
\hline
\end{tabular}

Notes: * In this study, "entrepreneurial experience" is defined as "experience in founding, owning, and running a corporation that paid salaries and wages to employees and owners, as well as all other expenses, for three or more months." Individuals with entrepreneurial experience are categorized as ENTRE_CONTINUE if they are currently involved in business start-ups, and are categorized as ENTRE_STOP if they retired or closed their businesses 
Table 2 Descriptive statistics of variables

\begin{tabular}{lrrrrrrrr}
\hline Variables & \multicolumn{1}{c}{$N$} & Mean & \multicolumn{1}{c}{ S.D. } & Min. & p25 & Median & p75 & Max. \\
\hline SATISF & 6092 & 3.13 & 1.12 & 1.00 & 2.00 & 3.00 & 4.00 & 5.00 \\
ENTRE_ & 6092 & 0.10 & 0.30 & 0.00 & 0.00 & 0.00 & 0.00 & 1.00 \\
ENTRE_STOP & 6092 & 0.04 & 0.20 & 0.00 & 0.00 & 0.00 & 0.00 & 1.00 \\
ENTRE_CONTINUE & 6092 & 0.06 & 0.23 & 0.00 & 0.00 & 0.00 & 0.00 & 1.00 \\
HINC & 5220 & 3.59 & 1.00 & 1.00 & 3.00 & 4.00 & 4.00 & 7.00 \\
CASH & 4789 & 2.76 & 1.73 & 1.00 & 1.00 & 2.00 & 4.00 & 7.00 \\
ASSET & 4222 & 2.68 & 1.90 & 1.00 & 1.00 & 2.00 & 4.00 & 7.00 \\
DEBT & 5145 & 1.85 & 1.49 & 1.00 & 1.00 & 1.00 & 2.00 & 7.00 \\
FEMALE & 6092 & 0.41 & 0.49 & 0.00 & 0.00 & 0.00 & 1.00 & 1.00 \\
AGE & 6092 & 45.26 & 13.32 & 18.00 & 35.00 & 45.00 & 55.00 & 79.00 \\
MARRIED & 6092 & 0.68 & 0.47 & 0.00 & 0.00 & 1.00 & 1.00 & 1.00 \\
NCHID & 6092 & 1.03 & 1.11 & 0.00 & 0.00 & 1.00 & 2.00 & 4.00 \\
\hline
\end{tabular}

Notes: $N$ indicates the number of observations. S.D. indicates standard deviation

One reason is that some entrepreneurs recognize true market conditions, including income, through their business practices after starting businesses, since nascent entrepreneurs have less information on the conditions before it. These entrepreneurs may have lower subjective well-being due to unexpected income, in addition to an increase in debt. Another reason is that while entrepreneurs tend to encounter unstable income, employees in Japan - especially those in established firms - are more likely to be given favorable conditions, such as long-term employment and employee pension. Even though entrepreneurs are more likely to gain freedom, they face pressure in securing not only their own income and pension, but also their employees' employment and pension. Entrepreneurs may also evaluate subjective well-being based on successful business outcomes. Moreover, some individuals are obliged to become successor entrepreneurs, simply because of the succession of businesses and technologies

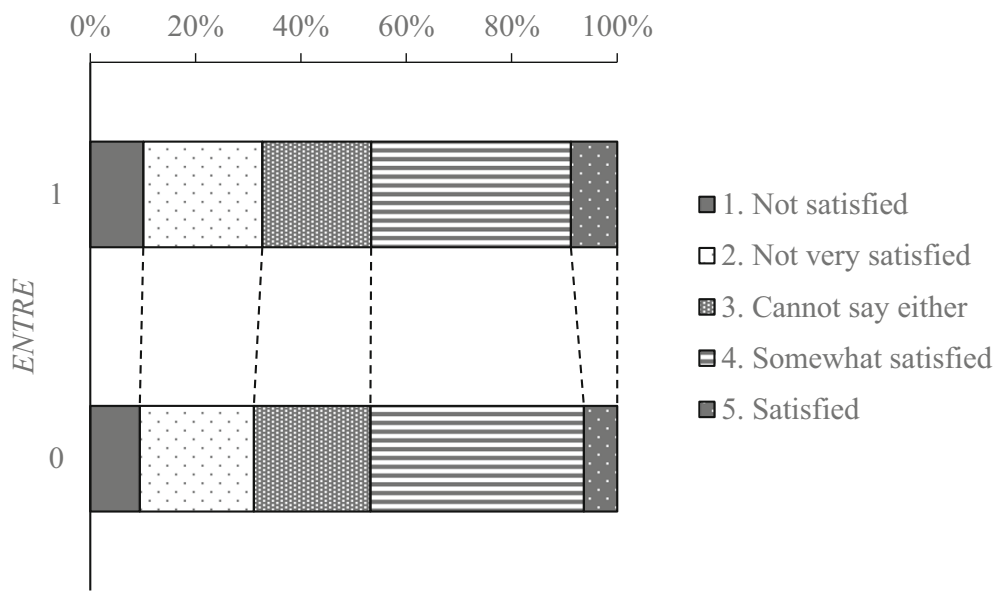

Fig. 1 Subjective well-being by entrepreneurial experience 
(a)

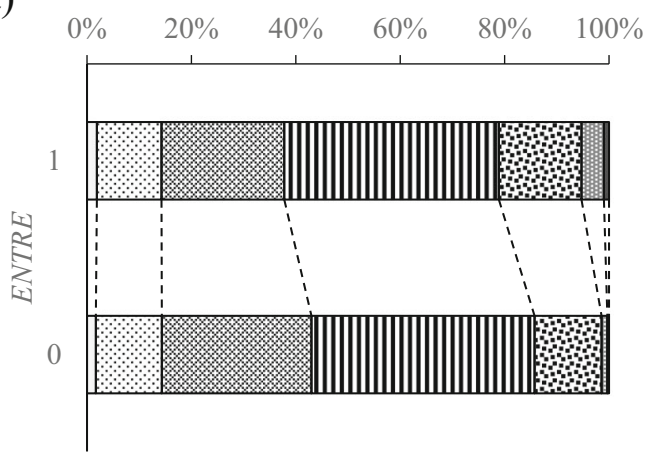

ㅁ. $<1$ million yen

⒉ 1-3 million yen

图3. 3-5 million yen

[U4. 5-10 million yen

옹 5. 10-20 million yen

ㄴ. 6 6. 20-50 million yen

$\square 7.50$ million yen +

(b)

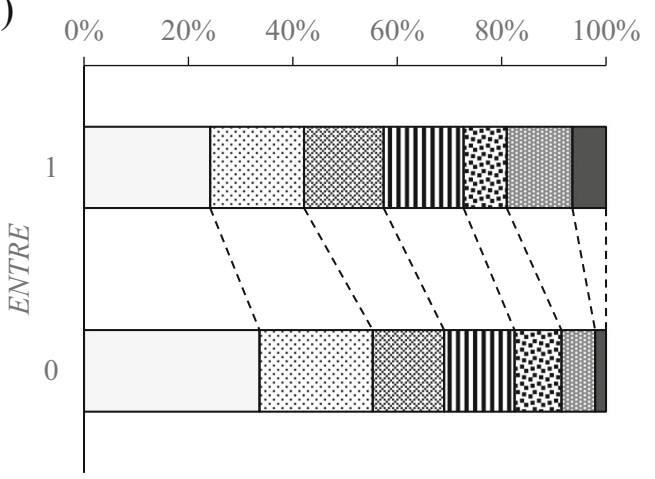

$\square 1 .<1$ million yen

๑2. 1-3 million yen

圈3. 3-5 million yen

[d 4- 5-10 million yen

명 5. 10-20 million yen

ㄴ. 20-50 million yen

7. 50 million yen +

(c)

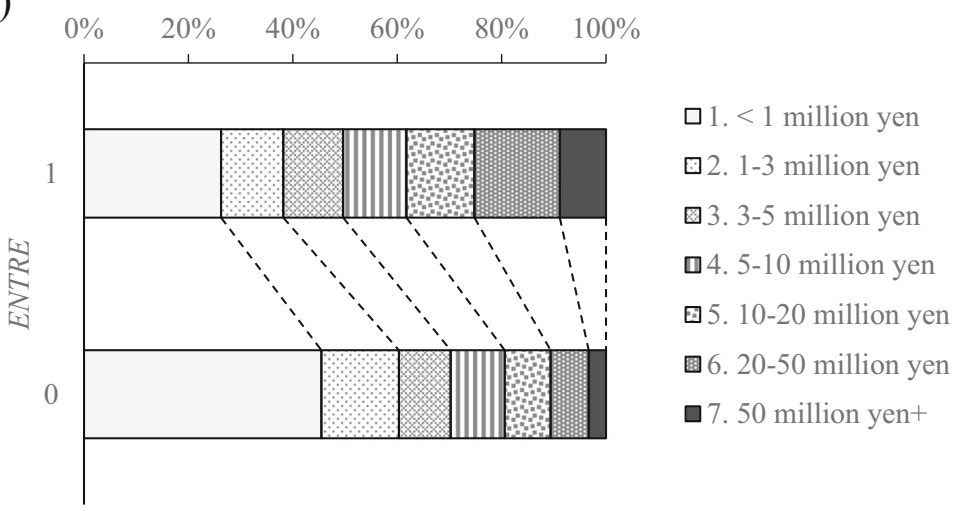

Fig. 2 Wealth by entrepreneurial experience. (a) Household income, (b) Cash and deposits, (c) Assets other than cash and deposits

developed by their family members, and others become entrepreneurs due to the lack of employment opportunities. This may be especially seen in Japan due to aging population. Such entrepreneurs may not have higher subjective well-being without a certain level of wealth.

Regarding the indirect effect of entrepreneurial experience on subjective well-being, we examine whether the level of wealth, measured by household income and individual 


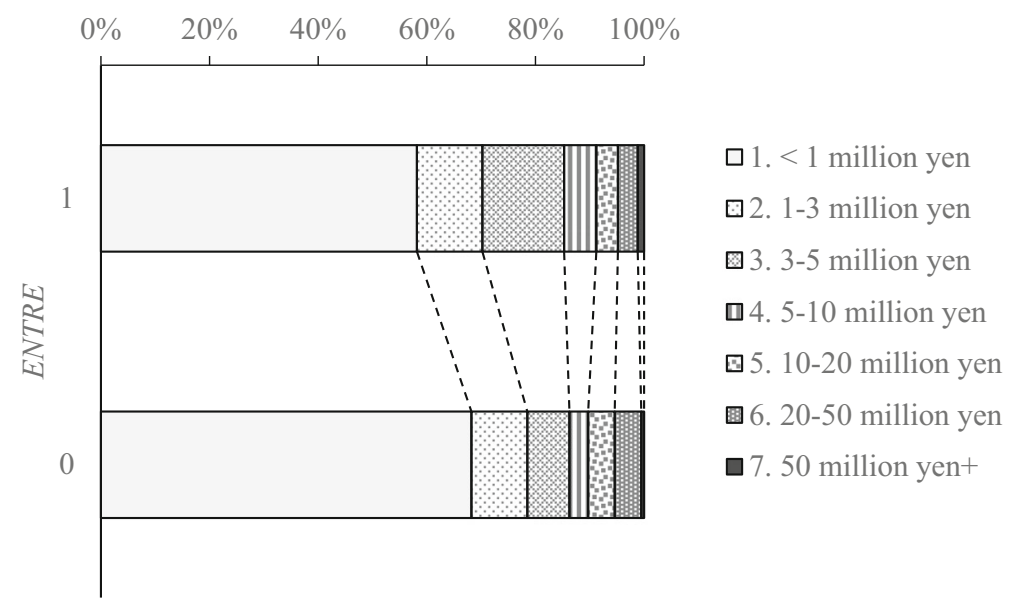

Fig. 3 Debt by entrepreneurial experience

cash and assets, mediates the association between entrepreneurial experience and subjective well-being. In Table 3, the coefficient of entrepreneurial experience is positive and significant for the level of wealth. In addition, the coefficient of the level of wealth is positive and significant for subjective well-being. We find a positive relationship between entrepreneurial experience and wealth and a positive relationship between wealth and subjective well-being. This is consistent with the findings of Block and Koellinger (2009). We provide supportive evidence on the indirect effect of entrepreneurial experience on subjective well-being through wealth. This indicates that individuals with entrepreneurial experience are more likely to have higher subjective well-being as they have higher incomes and assets. Our findings suggest that the level of wealth plays a critical role in determining subjective well-being in individuals, including entrepreneurs.

Moreover, we examine whether the level of debt mediates the association between entrepreneurial experience and subjective well-being. As Table 3 shows, debt has a negative and significant effect on subjective well-being, while entrepreneurial experience has a positive and significant effect on debt. The results reveal that entrepreneurial experience is associated with subjective well-being through debt, as well as wealth, although the relationship is opposite. Our findings suggest that the level of debt also plays a critical role in determining subjective well-being in individuals, including entrepreneurs.

Regarding the impact of personal attributes as control variables, the coefficient of $\ln A G E$ for subjective well-being is negative and significant, while the coefficient of FEMALE is less significant. The results indicate that younger individuals are more likely to have higher subjective well-being. The coefficient of MARRIED for subjective well-being is positive and significant, indicating that married individuals have higher subjective well-being than non-married ones.

In Table 4, we estimate the direct, indirect, and total effects of entrepreneurial experience on subjective well-being. We do not find total effects of entrepreneurial experience on subjective well-being, although its direct effect is negative. More importantly, the indirect effect of entrepreneurial experience through wealth and debt 
Table 3 Estimation results for subjective well-being (GSEM)

\begin{tabular}{|c|c|c|c|c|c|c|c|}
\hline & SATISF & WEALTH ${ }^{\#}$ & $D E B T^{\#}$ & HINC & $\mathrm{CASH}$ & ASSET & $D E B T$ \\
\hline ENTRE & $\begin{array}{l}-0.083^{*} \\
(0.049)\end{array}$ & $\begin{array}{l}0.177^{* * *} \\
(0.029)\end{array}$ & $\begin{array}{l}0.216^{* * *} \\
(0.078)\end{array}$ & & & & \\
\hline FEMALE & $\begin{array}{l}0.063^{*} \\
(0.038)\end{array}$ & $\begin{array}{l}-0.184^{* * * *} \\
(0.019)\end{array}$ & $\begin{array}{l}-0.851^{* * * *} \\
(0.053)\end{array}$ & & & & \\
\hline $\ln A G E$ & $\begin{array}{l}-0.461^{* * * *} \\
(0.058)\end{array}$ & $\begin{array}{l}0.551^{* * *} \\
(0.035)\end{array}$ & $\begin{array}{l}-0.701^{* * * *} \\
(0.089)\end{array}$ & & & & \\
\hline MARRIED & $\begin{array}{l}0.399^{* * * *} \\
(0.048)\end{array}$ & $\begin{array}{l}0.135^{* * *} \\
(0.029)\end{array}$ & $\begin{array}{l}0.452^{* * *} \\
(0.081)\end{array}$ & & & & \\
\hline$N C I L D(=0)$ & Omitted & Omitted & Omitted & & & & \\
\hline NCHILD $(=1)$ & $\begin{array}{l}-0.005 \\
(0.053)\end{array}$ & $\begin{array}{l}-0.034 \\
(0.032)\end{array}$ & $\begin{array}{l}0.292^{* * *} \\
(0.089)\end{array}$ & & & & \\
\hline NCHILD (=2) & $\begin{array}{l}0.096^{* *} \\
(0.048)\end{array}$ & $\begin{array}{l}-0.019 \\
(0.029)\end{array}$ & $\begin{array}{l}0.367^{* * * *} \\
(0.081)\end{array}$ & & & & \\
\hline NCHILD $(=3)$ & $\begin{array}{l}0.146^{* *} \\
(0.062)\end{array}$ & $\begin{array}{l}-0.098^{* * *} \\
(0.037)\end{array}$ & $\begin{array}{l}0.569^{* * *} \\
(0.100)\end{array}$ & & & & \\
\hline NCHILD (=4) & $\begin{array}{l}0.177 \\
(0.133)\end{array}$ & $\begin{array}{l}-0.216^{\text {**** }} \\
(0.081)\end{array}$ & $\begin{array}{l}0.477^{* *} \\
(0.215)\end{array}$ & & & & \\
\hline WEALTH $H^{\#}$ & $\begin{array}{l}0.557^{* * * *} \\
(0.040)\end{array}$ & & & $\begin{array}{l}1 \\
\text { Const. }\end{array}$ & $\begin{array}{l}2.699^{\text {**** }} \\
(0.153)\end{array}$ & $\begin{array}{l}3.202^{\text {*** }} \\
(0.216)\end{array}$ & \\
\hline$D E B T^{\#}$ & $\begin{array}{l}-0.103^{* * * *} \\
(0.027)\end{array}$ & & & & & & $\begin{array}{l}1 \\
\text { Const. }\end{array}$ \\
\hline cut1 & $\begin{array}{l}-1.400^{* * *} \\
(0.189)\end{array}$ & & & $\begin{array}{l}-0.334^{* *} \\
(0.130)\end{array}$ & $\begin{array}{l}4.810^{* * *} \\
(0.375)\end{array}$ & $\begin{array}{l}6.350^{* * * *} \\
(0.513)\end{array}$ & $\begin{array}{l}-1.775^{\text {*** }} \\
(0.321)\end{array}$ \\
\hline cut2 & $\begin{array}{l}-0.516^{* * *} \\
(0.188)\end{array}$ & & & $\begin{array}{l}0.864^{* * *} \\
(0.127)\end{array}$ & $\begin{array}{l}5.812^{\text {**** }} \\
(0.393)\end{array}$ & $\begin{array}{l}7.123^{\text {**** }} \\
(0.535)\end{array}$ & $\begin{array}{l}-1.295^{\text {*** }} \\
(0.321)\end{array}$ \\
\hline cut3 & $\begin{array}{l}0.095 \\
(0.188)\end{array}$ & & & $\begin{array}{l}1.864^{* * * *} \\
(0.128)\end{array}$ & $\begin{array}{l}6.466^{* * * *} \\
(0.405)\end{array}$ & $\begin{array}{l}7.689^{* * * *} \\
(0.552)\end{array}$ & $\begin{array}{l}-0.793^{* *} \\
(0.321)\end{array}$ \\
\hline cut4 & $\begin{array}{l}1.613^{* * *} \\
(0.189)\end{array}$ & & & $\begin{array}{l}3.289^{* * *} \\
(0.134)\end{array}$ & $\begin{array}{l}7.250^{\text {**** }} \\
(0.421)\end{array}$ & $\begin{array}{l}8.365^{\text {**** }} \\
(0.574)\end{array}$ & $\begin{array}{l}-0.502 \\
(0.321)\end{array}$ \\
\hline cut5 & & & & $\begin{array}{l}4.529^{* * *} \\
(0.144)\end{array}$ & $\begin{array}{l}8.013^{* * * *} \\
(0.439)\end{array}$ & $\begin{array}{l}9.142^{* * *} \\
(0.600)\end{array}$ & $\begin{array}{l}0.019 \\
(0.321)\end{array}$ \\
\hline cut6 & & & & $\begin{array}{l}5.225^{* * *} \\
(0.165)\end{array}$ & $\begin{array}{l}9.306^{\text {**** }} \\
(0.472)\end{array}$ & $\begin{array}{l}10.42^{* * * *} \\
(0.644)\end{array}$ & $\begin{array}{l}1.391^{* * *} \\
(0.331)\end{array}$ \\
\hline Var(error) & & $\begin{array}{l}0.278^{* * *} \\
(0.021)\end{array}$ & $\begin{array}{l}1 \\
\text { Const. }\end{array}$ & & & & \\
\hline$N$ & 6092 & & & & & & \\
\hline
\end{tabular}

Notes: Standard errors in parentheses. ${ }^{*} \mathrm{p}<0.1,{ }^{* *} \mathrm{p}<0.05,{ }^{* * *} \mathrm{p}<0.01 . N$ indicates the number of observations. Variables with subscript \# are latent variables

is significant. In particular, the positive effect of entrepreneurial experience on subjective well-being through wealth is observed, implying that entrepreneurs cannot achieve higher subjective well-being without a certain level of wealth. Further, the debt burden 


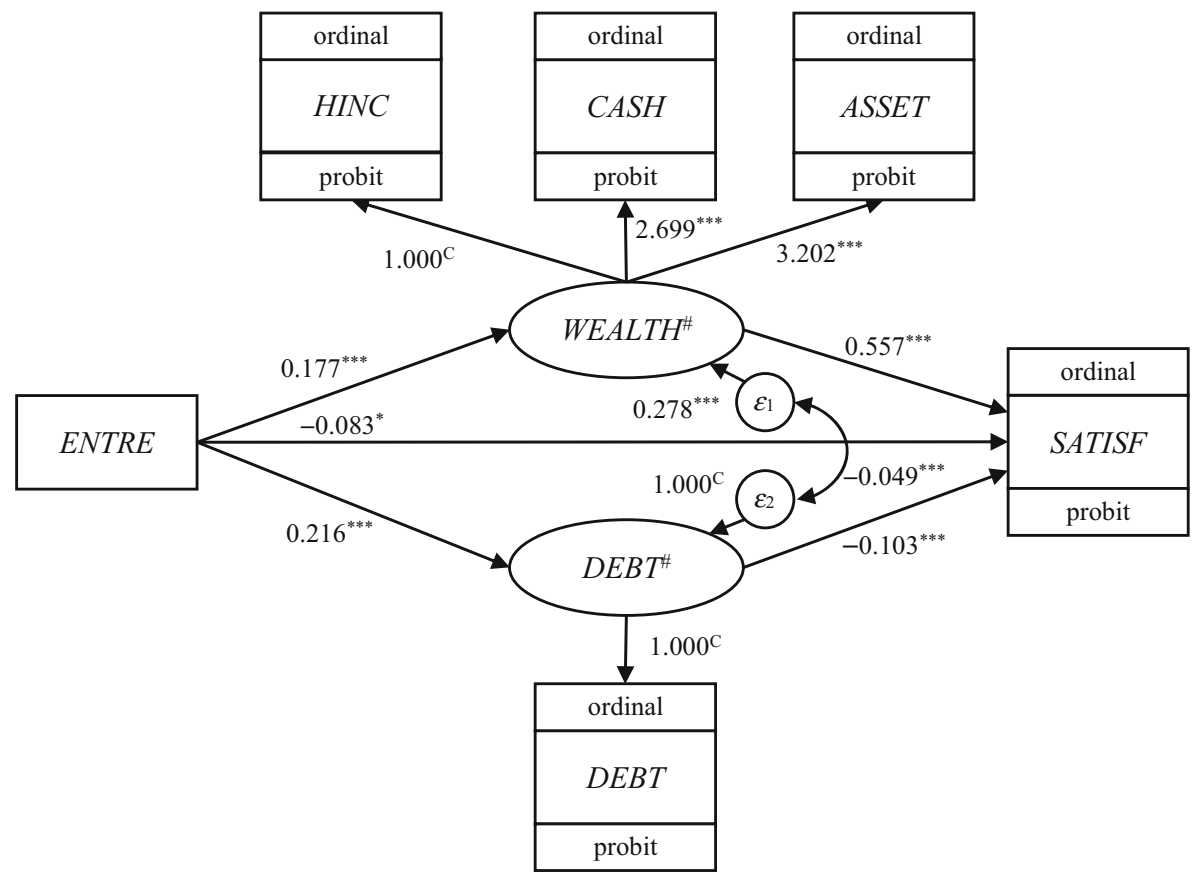

Fig. 4 Path diagram of subjective well-being (GSEM). Notes: The definitions of variables are presented in Table 1. The estimation results are presented in Table 3. Variables with superscript \# are latent variables. $\varepsilon_{1}$ and $\varepsilon_{2}$ are error terms. The estimated coefficients are adjacent to arrows. ${ }^{*} p<0.1,{ }^{* *} p<0.05,{ }^{* * *} p<0.01$. C indicates the coefficient constrained to a fixed value. The numbers outside error terms (circle) indicate the variance of errors. Control variables are also included in the model, but omitted from the figure. The number adjacent to the double-headed arrow indicates covariance

may reduce subjective well-being. The results indicate that the indirect effect of entrepreneurial experience plays a critical role in determining subjective well-being.

\section{Discussion}

This study contributes to the extant literature on entrepreneurial well-being by providing novel findings from an original survey in Japan. Although prior research on entrepreneurship has provided evidence on the presence of entrepreneurial well-being, there is still limited knowledge on the mediating effect of financial motives on entrepreneurial well-being. Our results indicate that entrepreneurial well-being does not simply result from starting a business. Even if individuals become entrepreneurs to seek their own interests, they do not necessarily have higher subjective well-being by starting their businesses. Rather, the level of wealth, which consists of financial motives, may enable individuals to secure subjective well-being derived from entrepreneurial experience. This is because a certain level of wealth is required to achieve subjective well-being through a business start-up, even though entrepreneurs with low income and long working hours have higher psychological motives, such as autonomy, than employees. Indeed, a low level of income reduces subjective well-being. In addition, we find that the level of debt reduces subjective well-being. Given that 
Table 4 Decomposition of the total effects of entrepreneurship experience on subjective well-being

\begin{tabular}{lrrrr}
\hline & Coef. & S.E. & $|\mathrm{z}|$ & $\mathrm{p}$ \\
\hline Direct effect & -0.083 & 0.049 & 1.710 & 0.088 \\
Indirect effect & 0.069 & 0.020 & 3.430 & 0.001 \\
via WEALTH & 0.096 & 0.017 & 5.600 & 0.000 \\
via DEBT & -0.027 & 0.011 & 2.480 & 0.013 \\
Total effects & -0.014 & 0.048 & -0.290 & 0.773 \\
\hline
\end{tabular}

Notes: S.E. indicates standard error. The number of observations is 6092 . Variables with superscript \# are latent variables

nascent entrepreneurs do not have an accurate prediction of business outcomes before starting their businesses, unexpected income and debt may reduce entrepreneurial wellbeing.

Moreover, this study provides new insight into the relationship between the subjective success measures (i.e., subjective well-being) and objective measures, which are captured by financial motives in this study. There are several types of measures to capture entrepreneurship. Both objective and subjective measures are useful for examining an individual's life satisfaction and assessing public support policy in the literature (e.g., Veenhoven 2002; Bhuiyan and Artjoms 2019; Zhao et al. 2021). In this respect, this study contributes to the extant literature by not only identifying the indirect effect of financial motives on subjective well-being, but also by emphasizing the importance of objective measures in the subjective success measure. This would be helpful in filling the gap between subjective and objective measures in research on entrepreneurship.

\section{Implications}

Entrepreneurial well-being allows individuals to create incentives to start businesses. This can lead to sustainable entrepreneurship in the economy. In reality, only few firms achieve high growth in a short period (Haltiwanger et al. 2013, 2017). Such highgrowth start-ups substantially contribute to the major part of economic growth (Shane 2008; Storey and Greene 2010).

The findings of this study provide some policy implications with regard to entrepreneurship. While policymakers have paid attention to the promotion of high-growth start-ups that can stimulate a stagnant economy, the level of entrepreneurship is still low in some countries, including Japan. As shown here, entrepreneurs do not necessarily have higher subjective well-being than others, suggesting that some employees have higher subjective well-being in Japan. Meanwhile, our findings suggest that the level of debt prevents individuals from becoming entrepreneurs. This may imply that the reduction of the mental burden associated with debt, including free property under the Bankruptcy Law, is required to promote entrepreneurship in Japan. ${ }^{6}$ On average,

\footnotetext{
${ }^{6}$ According to the Civil Execution Act (Article 131) in Japan, cash in the amount specified by a Cabinet Order based on an average household's necessary living expenses for two months shall not be seized, even when personal bankruptcy occurs. According to the Civil Execution Ordinance, this amount of cash (free property) is 990 thousand yen.
} 
becoming an entrepreneur may not be a better choice in some countries, including Japan. Such recognition prevents individuals from becoming entrepreneurs, which could result in the low entry rate in these countries. While policymakers often encourage entrepreneurship in regions and countries, it is unclear whether becoming an entrepreneur is a better choice for all individuals. It should be emphasized that policymakers should pay more attention to promoting individuals with a better understanding of the current environment for business start-ups, in addition to required entrepreneurial ability to achieve a certain level of income, rather than simply encouraging individuals to become entrepreneurs. Such policy shifts could create sustainable economic growth in an entrepreneurial ecosystem.

\section{Limitations and Future Research Directions}

There are some limitations to this study. First, although we used the smartphone and online computer survey to effectively secure a sufficient sample size, this might cause a selection bias resulting from easy online access. Second, we measured subjective wellbeing using the single-item measurement of life satisfaction, which could be quite simplistic, following the previous studies (e.g., Decancq et al. 2015; Kibler et al. 2019). We also measured entrepreneurial experience, regardless of an individual's age. Third, we could not identify whether the level of wealth is derived from starting a business. In addition, we could not identify whether subjective well-being is derived mainly from starting a business in the survey. Finally, we could not pay attention to the causal relationship between entrepreneurial experience and wealth, although previous studies have examined the impact of financial constraints, which are associated with wealth, on business start-ups (e.g., Evans and Jovanovic 1989; Holtz-Eakin et al. 1994a, 1994b). Further investigation will be warranted to elucidate the impact of business outcomes on entrepreneurial well-being.

\section{Conclusions}

This study investigated the relationship between entrepreneurial experience and subjective well-being. Using an original survey on subjective well-being, entrepreneurial experience, level of wealth, and personal attributes of 10,001 individuals in Japan, we examined the factors that mediate the association between entrepreneurial experience and subjective wellbeing. As a result, we found no significant evidence that individuals with entrepreneurial experience have higher subjective well-being. However, we found a positive indirect effect of entrepreneurial experience on subjective well-being through wealth and a negative indirect effect through debt. The findings of this study indicated the importance of considering the mediating effect of financial motives in entrepreneurial well-being.

Supplementary Information The online version contains supplementary material available at https:/doi.org/ 10.1007/s11482-021-09947-1.

Acknowledgements This study was conducted as a part of the Project "Creation and Development of Hightech Startups" undertaken at the Research Institute of Economy, Trade and Industry (RIETI), Japan. An earlier version of this study was presented at a seminar of the RIETI Discussion Paper. The authors are grateful for 
helpful comments and suggestions by RIETI project members and Discussion Paper seminar participants. The authors thank John Kitching for valuable comments and suggestions at the Research in Entrepreneurship and Small Business Conference held in Berlin. The authors also thank the editor and reviewer for insightful comments and suggestions.

Code Availability All data analyses in this study were performed using Stata software (version 16.0). If requested by the reader, our programming code (Stata do file format) used for the analyses can be provided by e-mail.

Funding This study was conducted as a part of the Project "Creation and Development of High-tech Startups" undertaken at the Research Institute of Economy, Trade and Industry (RIETI). This study was financially supported by a Grant-in-Aid for Scientific Research from the Japan Society for the Promotion of Science (JSPS) for the first author (Number: JP17K03713, JP20K01618).

Data Availability The data used in this study come from a smartphone and online computer survey, "Internet Survey on the Characteristics and Decision-Making of Potential Entrepreneurs and Angel Investors" of the research project of the RIETI. We cannot deposit the data because of the regulations of the RIETI.

\section{Declarations}

Conflict of Interest/Competing Interests Not applicable.

Open Access This article is licensed under a Creative Commons Attribution 4.0 International License, which permits use, sharing, adaptation, distribution and reproduction in any medium or format, as long as you give appropriate credit to the original author(s) and the source, provide a link to the Creative Commons licence, and indicate if changes were made. The images or other third party material in this article are included in the article's Creative Commons licence, unless indicated otherwise in a credit line to the material. If material is not included in the article's Creative Commons licence and your intended use is not permitted by statutory regulation or exceeds the permitted use, you will need to obtain permission directly from the copyright holder. To view a copy of this licence, visit http://creativecommons.org/licenses/by/4.0/.

\section{References}

Abreu, M., Oner, O., Brouwer, A., \& Van Leeuwen, E. (2019). Well-being effects of self-employment: A spatial inquiry. Journal of Business Venturing, 34, 589-607.

Akram, T. (2019). The Japanese economy: Stagnation, recovery, and challenges. Journal of Economic Issues, $53,403-410$.

Andersson, P. (2008). Happiness and health: Well-being among the self-employed. Journal of Socio Economics, 37, 213-236.

Åstebro, T., Herz, H., Nanda, R., Roberto, A., \& Weber, R. A. (2014). Seeking the roots of entrepreneurship: Insights from behavioral economics. Journal of Economic Perspectives, 28, 49-70.

Baron, R. A., \& Henry, R. C. (2010). How entrepreneurs acquire the capacity to excel: Insights from research on expert performance. Strategic Entrepreneurship Journal, 4, 49-65.

Baron, R., \& Kenny, D. (1986). The moderator-mediator variable distinction in social psychological research: Conceptual, strategic, and statistical considerations. Journal of Personality and Social Psychology, 51, 1173-1182.

Benz, M., \& Frey, B. S. (2008a). Being independent is a great thing: Subjective evaluations of selfemployment and hierarchy. Economica, 75, 362-383.

Benz, M., \& Frey, B. S. (2008b). The value of doing what you like: Evidence from the self-employed in 23 countries. Journal of Economic Behavior and Organization, 68, 445-455.

Bhuiyan, M. F., \& Artjoms, I. (2019). Micro-entrepreneurship and subjective well-being: Evidence from rural Bangladesh. Journal of Business Venturing, 34, 625-645.

Binder, M. (2013). Innovativeness and subjective well-being. Social Indicators Research, 111, 561-578. 
Binder, M., \& Coad, A. (2013). Life satisfaction and self-employment: A matching approach. Small Business Economics, 40, 561-578.

Blanchflower, D. (2000). Self-employment in OECD countries. Labour Economics, 7, 471-505.

Blanchflower, D., \& Oswald, A. (1998). What makes an entrepreneur? Journal of Labour Economics, 16, 2660.

Blanchflower, D., Oswald, A., \& Stutzer, A. (2001). Latent entrepreneurship across nations. European Economic Review, 45, 680-691.

Block, J., \& Koellinger, P. (2009). I can’t get no satisfaction-Necessity entrepreneurship and procedural utility. Kyklos, 62, 191-209.

Boyd, N. G., \& Vozikis, G. S. (1994). The influence of self-efficacy on the development of entrepreneurial intentions and actions. Entrepreneurship Theory and Practice, 18, 63-77.

Bradley, D. F., \& Roberts, J. A. (2004). Self-employment and job satisfaction: Investigating the role of selfefficacy, depression, and seniority. Journal of Small Business Management, 42, 37-58.

Brüggen, E. C., Hogreve, J., Holmlund, M., Kabadayi, S., \& Löfgren, M. (2017). Financial well-being: A conceptualization and research agenda. Journal of Business Research, 79, 228-237.

Carree, M. A., \& Verheul, I. (2012). What makes entrepreneurs happy? Determinants of satisfaction among founders. Journal of Happiness Studies, 13, 371-387.

Carter, S. (2011). The rewards of entrepreneurship: Exploring the incomes, wealth, and economic well-being of entrepreneurial households. Entrepreneurship Theory and Practice, 35, 39-55.

Clark, A. E., Frijters, P., \& Shields, M. A. (2008). Relative income, happiness, and utility: An explanation for the easterlin paradox and other puzzles. Journal of Economic Literature, 45, 95-144.

Cooper, D., \& Peake, W. O. (2018). Commentary: Family member well-being in the kinship enterprise: A self-determination perspective. Entrepreneurship Theory and Practice, 42, 340-345.

Cueto, B., \& Pruneda, G. (2017). Job satisfaction of wage and self-employed workers. Do job preferences make a difference? Applied Research in Quality of Life, 12, 103-123.

Cummins, R. A. (2000). Personal income and subjective well-being: A review. Journal of Happiness Studies, $1,133-158$.

Decancq, K., Fleurbaey, M., \& Schokkaert, E. (2015). Happiness, equivalent incomes and respects for individual preferences. Economica, 82, 1082-1106.

Deci, E. L., \& Ryan, R. M. (2000). The "what" and "why" of goal pursuits: Human needs and the selfdetermination of behavior. Psychological Inquiry, 11, 227-268.

Diener, E., Suh, E. M., Lucas, R. E., \& Smith, H. L. (1999). Subjective well-being: Three decades of progress. Psychological Bulletin, 125, 276-302.

Dijkhuizen, J., Gorgievski, M., Van Veldhoven, M., \& Schalk, R. (2018). Well-being, personal success and business performance among entrepreneurs: A two-wave study. Journal of Happiness Studies, 19, $2187-$ 2204.

Dolan, P., Peasgood, T., \& White, M. (2008). Do we really know what makes us happy? A review of the economic literature on the factors associated with subjective well-being. Journal of Economic Psychology, 29, 94-122.

Easterlin, R. A. (1974). Does economic growth improve the human lot? Some empirical evidence. In P. David \& M. Reder (Eds.), Nations and households in economic growth (pp. 89-125). Academic Press.

Evans, D. S., \& Jovanovic, B. (1989). An estimated model of entrepreneurial choice under liquidity constraints. Journal of Political Economy, 97, 808-827.

Feldman, D. C., \& Bolino, M. C. (2000). Career patterns of the self-employed: Career motivations and career outcomes. Journal of Small Business Management, 38, 53-67.

Forbes, D. P. (2005). Are some entrepreneurs more overconfident than others? Journal of Business Venturing, 20, 623-640.

Gunzler, D., Chen, T., Wu, P., \& Zhang, H. (2013). Introduction to mediation analysis with structural equation modeling. Shanghai Archives of Psychiatry, 25, 390-394.

Haltiwanger, J., Jarmin, R., Kulick, R., \& Miranda, J. (2017). High growth young firms: Contribution to job, output and productivity growth. In J. Haltiwanger, E. Hurst, J. Miranda, \& A. Schoar (Eds.), Measuring entrepreneurial businesses: Current knowledge and challenges (pp. 11-62). University of Chicago Press.

Haltiwanger, J., Jarmin, R., \& Miranda, J. (2013). Who creates jobs? Small versus large versus young. Review of Economics and Statistics, 95, 347-361.

Hamilton, B. (2000). Does entrepreneurship pay? An empirical analysis of the returns to self-employment. Journal of Political Economy, 108, 604-631.

Hatak, I., \& Zhou, H. (2021). Health as human capital in entrepreneurship: Individual, extension, and substitution effects on entrepreneurial success. Entrepreneurship Theory and Practice, 45, 18-42.

Hayes, A. F. (2018). Introduction to mediation, moderation, and conditional process analysis. Guilford Press. 
Headey, B., \& Wooden, M. (2004). The effects of wealth and income on subjective well-being and ill-being. Economic Record, 80, S24-S33.

Hessels, J., Rietveld, C. A., Thurik, A. R., \& Van del Zwan, P. (2018). Depression and entrepreneurial exit. Academy of Management Perspectives, 32, 323-339.

Holtz-Eakin, D., Joulfaian, D., \& Rosen, H. S. (1994a). Entrepreneurial decisions and liquidity constraints. Rand Journal of Economy, 25, 334-347.

Holtz-Eakin, D., Joulfaian, D., \& Rosen, H. S. (1994b). Sticking it out: Entrepreneurial survival and liquidity constraints. Journal of Political Economy, 102, 53-75.

Honjo, Y. (2015). Why are entrepreneurship levels so low in Japan? Japan and the World Economy, 36, 88101.

Honjo, Y., \& Nakamura, H. (2020). The link between entrepreneurship and informal investment: An international comparison. Japan and the World Economy, 54, 101012.

Hurst, E., \& Lusardi, A. (2004). Liquidity constraints, household wealth, and entrepreneurship. Journal of Political Economy, 112, 319-347.

Hyytinen, A., \& Ruuskanen, O.-P. (2007). Time use of the self-employed. Kyklos, 60, 105-122.

Jenkins, A. S., Wiklund, J., \& Brundin, E. (2014). Individual responses to firm failure: Appraisals, grief, and the influence of prior failure experience. Journal of Business Venturing, 29, 17-33.

Jovanovic, B. (1982). Selection and the evolution of industry. Econometrica, 50, 649-670.

Judge, T. A., Piccolo, R. F., Podsakoff, N. P., Shaw, J. C., \& Rich, B. L. (2010). The relationship between pay and job satisfaction: A meta-analysis of the literature. Journal of Vocational Behavior, 77, 157-167.

Kahneman, D., \& Deaton, A. (2010). High income improves evaluation of life but not emotional well-being. Proceedings of the National Academy of Sciences, 107, 16489-16493.

Kautonen, T., \& Palmroos, J. (2010). The impact of a necessity-based start-up on subsequent entrepreneurial satisfaction. International Entrepreneurship and Management Journal, 6, 285-300.

Kibler, E., Wincent, J., Kautonen, T., Cacciotti, G., \& Obschonka, M. (2019). Can prosocial motivation harm entrepreneurs' subjective well-being? Journal of Business Venturing, 34, 608-624.

Klug, H. J. P., \& Maier, G. W. (2015). Linking goal progress and subjective well-being. Journal of Happiness Studies, 16, 37-65.

Koellinger, P., Minniti, M., \& Schade, C. (2007). "I think I can, I think I can”: Overconfidence and entrepreneur behavior. Journal of Economic Psychology, 28, 502-527.

Lindblom, A., Lindblom, T., \& Wechtler, H. (2020). Dispositional optimism, entrepreneurial success and exit intentions: The mediating effects of life satisfaction. Journal of Business Research, 120, 230-240.

Lofstrom, M., Bates, T., \& Parker, S. C. (2014). Why are some people more likely to become small-businesses owners than others: Entrepreneurship entry and industry-specific barriers. Journal of Business Venturing, $29,232-251$.

Lyubomirsky, S., Sheldon, K. M., \& Schkade, D. (2005). Pursuing happiness: The architecture of sustainable change. Review of General Psychology, 9, 111-131.

MacKinnon, D. P. (2017). Introduction to statistical mediation analysis. Routledge.

Marshall, D. R., Meek, W. R., Swab, R. G., \& Markin, E. (2020). Access to resources and entrepreneurial well-being: A self-efficacy approach. Journal of Business Research, 120, 203-212.

Millán, J. M., Hessels, J., Thurik, R., \& Aguado, R. (2013). Determinants of job satisfaction: A European comparison of self-employed and paid employees. Small Business Economics, 40, 651-670.

Monsen, E., \& Boss, R. W. (2009). The impact of strategic entrepreneurship inside the organization: Examining job stress and employee retention. Entrepreneurship Theory and Practice, 33, 71-104.

Naudé, W., Amorós, J. E., \& Cristi, O. (2014). "Surfeiting, the appetite may sicken": Entrepreneurship and happiness. Small Business Economics, 42, 523-540.

Nikolaev, B., Boudreaux, C. J., \& Wood, M. (2020a). Entrepreneurship and subjective well-being: The mediating role of psychological functioning. Entrepreneurship Theory and Practice, 44, 557-586.

Nikolaev, B., Shir, N., \& Wiklund, J. (2020b). Dispositional positive and negative affect and self-employment transitions: The mediating role of job satisfaction. Entrepreneurship Theory and Practice, 44, 451-474.

Oshio, T., \& Kobayashi, M. (2011). Area-level income inequality and individual happiness: Evidence from Japan. Journal of Happiness Studies, 12, 633-649.

Parasuraman, S., \& Simmers, C. (2001). Type of employment, work-family conflict and well-being: A comparative study. Journal of Organizational Behavior, 22, 551-568.

Porter, N. M., \& Garman, E. T. (1992). Money as part of a measure of financial well-being. American Behavioral Scientist, 35, 820-826.

Przepiorka, A. M. (2017). Psychological determinants of entrepreneurial success and life-satisfaction. Current Psychology, 36, 304-315. 
Ryff, C. D. (2019). Entrepreneurship and eudaimonic well-being: Five venues for new science. Journal of Business Venturing, 34, 646-663.

Shane, S. A. (2008). The illusions of entrepreneurship: The costly myths that entrepreneurs, investors, and policy makers live by. Yale University Press.

Sheldon, K. M., \& Houser-Marko, L. (2001). Self-contradance, goal attainment, and the pursuit of happiness: Can there be an upward spiral? Journal of Personality and Social Psychology, 80, 152-165.

Sheldon, K. M., Kasser, T., Smith, K., \& Share, T. (2002). Personal goals and psychological growth: Testing an intervention to enhance goal attainment and personality integration. Journal of Personality, 70, 5-31.

Shepherd, D. A., Wennberg, K., Suddaby, R., \& Wiklund, J. (2019). What are we explaining? A review and agenda on initiating, engaging, performing, and contextualizing entrepreneurship. Journal of Management, 45, 159-196.

Sherman, C. L., Randall, C., \& Kauanui, S. K. (2016). Are you happy yet? Entrepreneurs' subjective wellbeing. Journal of Management, Spirituality and Religion, 13, 7-23.

Shir, N., Nikolaev, B. N., \& Wincent, J. (2019). Entrepreneurship and well-being: The role of psychological autonomy, competence, and relatedness. Journal of Business Venturing, 34, 105875.

Small and Medium Enterprise Agency (Ed.). (2017). The 2017 white paper on small and medium enterprises in Japan. National Association of Trade Promotion for Small and Medium Enterprises.

Small and Medium Enterprise Agency (Ed.) (2019). Chushokigyo hakusho 2019 nenban [The 2019 white paper on small enterprises in Japan] (in Japanese). Tokyo: Nikkei Printing.

Sorgente, A., \& Lanz, M. (2017). Emerging adults' financial well-being: A scoping review. Adolescent Research Review, 2, 255-292.

Stephan, U. (2018). Entrepreneurs' mental health and well-being: A review and research agenda. Academy of Management Perspectives, 32, 290-322.

Stevenson, B., \& Wolfers, J. (2008). Economic growth and subjective well-being: Reassessing the Easterlin paradox. Brooking Papers on Economic Activity, 2008, 1-87.

Stevenson, B., \& Wolfers, J. (2013). Subjective well-being and income: Is there any evidence of satiation? American Economic Review, 103, 598-604.

Storey, D. J., \& Greene, F. J. (2010). Small business and entrepreneurship. Pearson Education.

Taniguchi, H., \& Potter, D. A. (2016). Who are your neighbors? Neighbor relationships and subjective wellbeing in Japan. Applied Research in Quality of Life, 11, 1425-1443.

Tiefenbach, T., \& Kohlbacher, F. (2015). Happiness in Japan in times of upheaval: Empirical evidence from the national survey on lifestyle preferences. Journal of Happiness Studies, 16, 333-366.

Tremblay, D.-G., \& Genin, E. (2008). Money, work-life balance and autonomy: Why do IT professionals choose self-employment? Applied Research in Quality of Life, 3, 161-179.

Uy, M. A., Sun, S., \& Foo, M.-D. (2017). Affect spin, entrepreneurs' well-being, and venture goal progress: The moderating role of goal orientation. Journal of Business Venturing., 32, 443-460.

Van de Ven, A. H., Sapienza, H. J., \& Villanueva, J. (2007). Entrepreneurial pursuits of self- and collective interests. Strategic Entrepreneurship Journal, 1, 353-370.

Van Praag, B. M. S., Frijters, P., \& Ferrer-i-Carbonell, A. (2003). The anatomy of subjective well-being. Journal of Economic Behavior and Organization, 51, 29-49.

Van der Zwan, P., Hessels, J., \& Rietveld, C. A. (2018). Self-employment and satisfaction with life, work, and leisure. Journal of Economic Psychology, 64, 73-88.

Veenhoven, R. (2002). Why social policy needs subjective indicators. Social Indicators Research, 58, 33-45.

Wiklund, J., Nikolaev, B., Shir, N., Foo, M.-D., \& Bradley, S. (2019). Entrepreneurship and well-being: Past, present, and future. Journal of Business Venturing, 34, 579-588.

Wills, E. (2009). Spirituality and subjective well-being: Evidences for a new domain the personal well-being index. Journal of Happiness Studies, 10, 49-69.

Zhao, H., O’Connor, G., Wu, J., \& Lumpkin, G. T. (2021). Age and entrepreneurial career success: A review and meta-analysis. Journal of Business Venturing, 36, 106007.

Publisher's Note Springer Nature remains neutral with regard to jurisdictional claims in published maps and institutional affiliations. 


\section{Affiliations}

\section{Yuji Honjo ${ }^{1} \cdot$ Kenta Ikeuchi $^{2} \cdot$ Hiroki Nakamura ${ }^{3}$}

1 Faculty of Commerce, Chuo University, 742-1 Higashinakano, Hachioji, Tokyo 192-0393, Japan

2 Research Institute of Economy, Trade and Industry, 1-3-1 Kasumigaseki, Chiyoda, Tokyo 1008901, Japan

3 Institute of Social Science, The University of Tokyo, 7-3-1 Hongo, Bunkyo-ku, Tokyo 113-0033, Japan 